\title{
Structural Study and Analytical Modeling of Mangerak Salt Diapir (South West of Firozabad Fars-Iran)
}

\author{
Anahita Keynejad \\ Islamic Azad University of Chalus, Chalus, Iran \\ Email: anahita.keynezhad@gmail.com
}

How to cite this paper: Keynejad, A. (2017) Structural Study and Analytical Modeling of Mangerak Salt Diapir (South West of Firozabad Fars-Iran). Open Journal of Geo$\log , 7,12-30$.

http://dx.doi.org/10.4236/ojg.2017.71002

Received: July 4, 2016

Accepted: January 13, 2017

Published: January 16, 2017

Copyright $\odot 2017$ by author and Scientific Research Publishing Inc. This work is licensed under the Creative Commons Attribution International License (CC BY 4.0).

http://creativecommons.org/licenses/by/4.0/

\begin{abstract}
Mangerak salt diapir is in the South West of Firuz Abad in Fars province, southern Iran and structurally, it is exposed in the simple folded belt of Kohzad Zagros. This diapir, now, is located in a transtentional zone in the overlapping parts of Koreh Bas right fault zone. The origin of this diapir is evaporative series of Hormuz, at the beginning of the Cambrian and ending Precambrian age. In this paper, we investigated tectonic structures around the salt dome of Mangerak. By promoting this salt dome, a variety of structures, such as marginal reverse faults, radial normal faults, folds and caves have been developed. In addition, many changes can be seen in the status line, and the amount and direction of the strata dip, thickness of rock units, and facies change, that all showed the downbuilding phenomenon in the diapir. The method was based on structural desert surveys and relevant measurements. The results show that salt domes above were rising during the Late CretaceousPaleocene, and pre-deformation of Zagros and in connection with basement Fault of Korebas, and probably, when sedimentation was in the Zagros basin, they have been exposed in the form of an island. Zagros deformation at the same time, the pressure released from the collision zone on the north side of the East and its wave motion, to the South West, exerts more pressure on the salt horizons and helps them to erupt. About Mangerak salt dome, which is exposed on the side of the Sayakh anticline axis and Basement fault of Korebas, two phenomena are effective in its exposing. Analytical modeling shows the life of the outcrop 31,000 years that this age is consistent with the effects of salt dome Neotectonic.
\end{abstract}

\section{Keywords}

Diapirism, Zagros, Salt Domes of Mangerak, Structural Deformation, Analytical Modeling 


\section{Introduction}

Drift Zagros fold belt is located in the middle of mountain belts Alpine-Himalayan, in the northeastern margin of the Arabic page [1] [2]. Fold Belt-Zagros thrust is the result of opening and closing the Tethys Ocean basin and continuous integration among the Arabic and Iranian block belongs to the Eurasian plate. The study area is located in the middle of the Zagros fold-thrust belt of Iran and the Fars region (Figure 1 and Figure 2). The Mangerak salt diapir is located 80 kilometers south-west of Shiraz. This diapir is exposed aligned with a piece of Bas fault zone (Figure 3). These twin domes have a length of $10 \mathrm{~km}$ and a width of 5 kilometers (Figure 4). The northern part is much smaller than its southern section. The fourth part of the Korebas fault system has caused the separation of right direction of the axis of the Sayakh anticline. This fault has cut the Sayakh anticline and has caused the level of salt in the core of the anticline reaches the surface (Figure 5). Then, north move to the west block of the fault, has caused part of the salt mass will be moved from its place, which causes the separation of isolated feeder roots in salt mass. This phenomenon has been made twin salt dome [3] [4] [5]. In the lower large part, deep-origin of salt is closed and salt rate will be more than the fed salt rate from below that is formed a flat parabolic profile similar to the water droplet mechanism. In general, the dome, in accordance with the Classification is considered in line with domes with salt and with a chimney

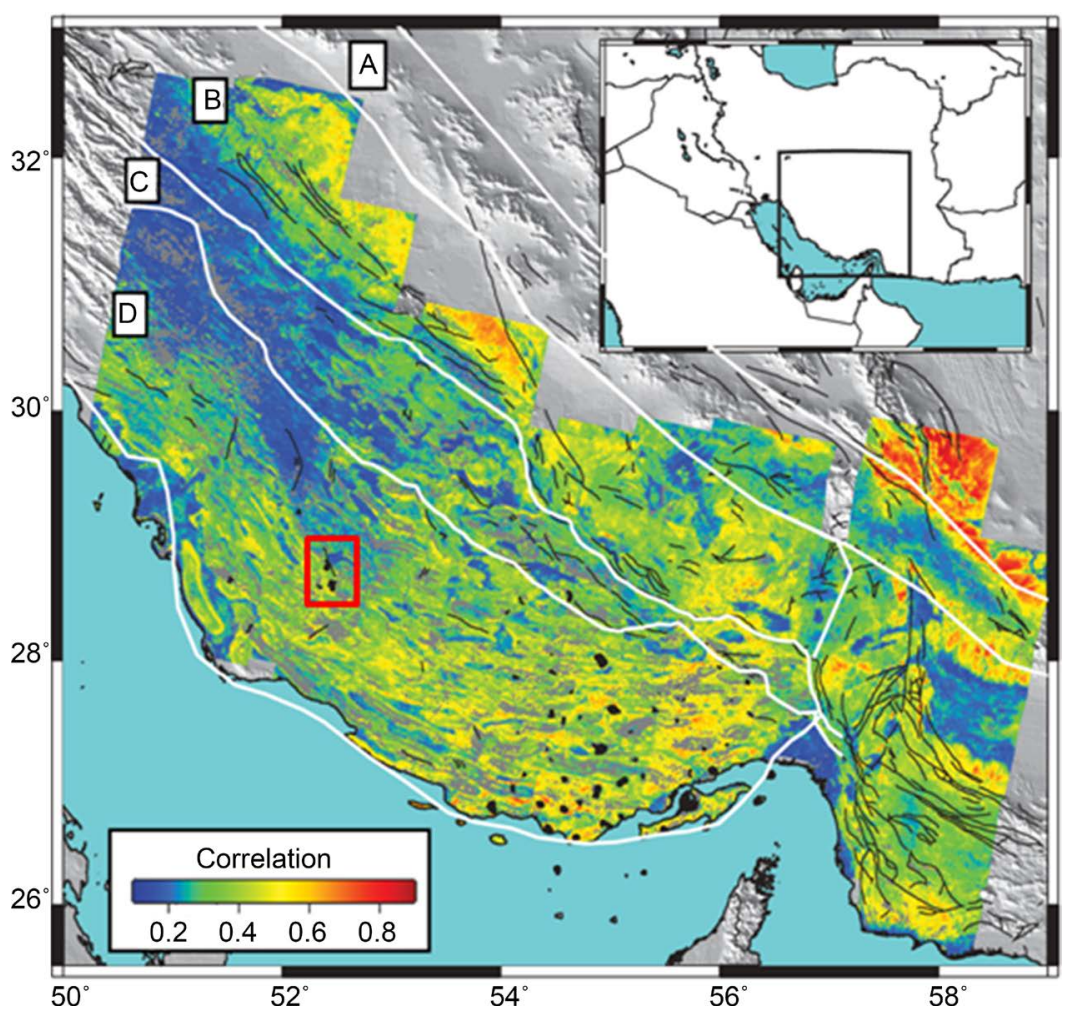

Figure 1. Map of tectonic provinces in Zagros orogenic belt, where the study place is shown with a red rectangle. A: Girl Urmia volcanic Bar; B: Sanandaj Sirjan zone; C: High Zagros; D: active Zagros fold-thrust belt. Black areas show the exposed salt domes and the black lines show faults with surface effects. 


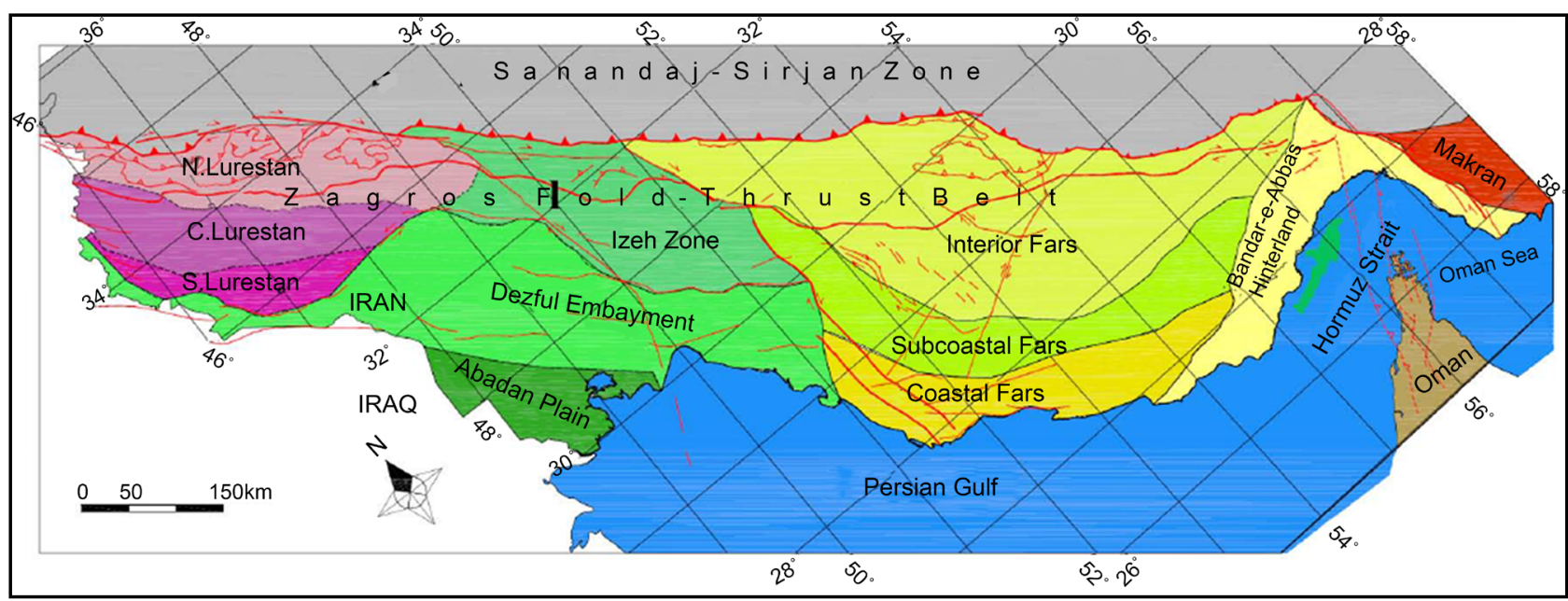

Figure 2. The main sub-divisions of the Zagros Fold-thrust Belt. The Zagros Fold-thrust Belt divided into three tectonic zones from the NE to the SW: the High Zagros, the Zagros simply folded belt, and the Zagros foredeep zone. The simply folded Zagros is subdivided according to its tectonic and sedimentary evolution into three domains; Lorestan, Izeh, and Fars areas. The Fars area is separated into four parts; Coastal, Sub-coastal, interior Fars and Bandarabbas hinterland. Study area is located in the interior Fars.

that is still in operation (Figure 6). On the other hand, rising salt domes have diversification and significant impact on the depositional environment, will involve a change in their primary structures (before rising), and will create the secondary structures. In this study, the aim is to evaluate all structural elements associated with the rise of diapir Mangerak and analytical modeling based on field evidence [6] [7] [8].

In this regard, regional structures such as folds, faults and fracture systems are identified, measured, analyzed, and their relationship with the de-dome is examined. With the study of data, analysis on faults and cracks of dome deformation systems, in the study area, the effect of faults will be examined on the movement and the emplacement of salt mass and Maren, in the current situation. Morphotectonics situation and karst formation associated with the rise of diapir was also considered and analytical modeling was used for the dome [9] [10].

\section{Tectonic Setting}

Zagros fold-thrust belt that is because of opening and closing new Tethys Ocean Territory [3], is formed by a thick sedimentary sequence late Precambrian to Pliocene age without angular unconformity zone [11] [12] [13]. This thick stratigraphic column covers the Precambrian rocks that are formed during the Pan African orogenic [14] [15]. The most ancient strata unit, in the belt of Hormuz salt, Payany-Cambrian Precambrian age is the beginning, but recently, a number of researchers, seismic stratigraphy that the lines have identified the following series of Hormuz directly foundations stone has been deposited. The oldest stratigraphic unit in this Belt is Hormuz salt with Precambrian-the beginning Cambrian age [16], but, recently, a number of researchers have identified stratigraphy on the seismic lines under the series of Hormuz that directly it is settled 


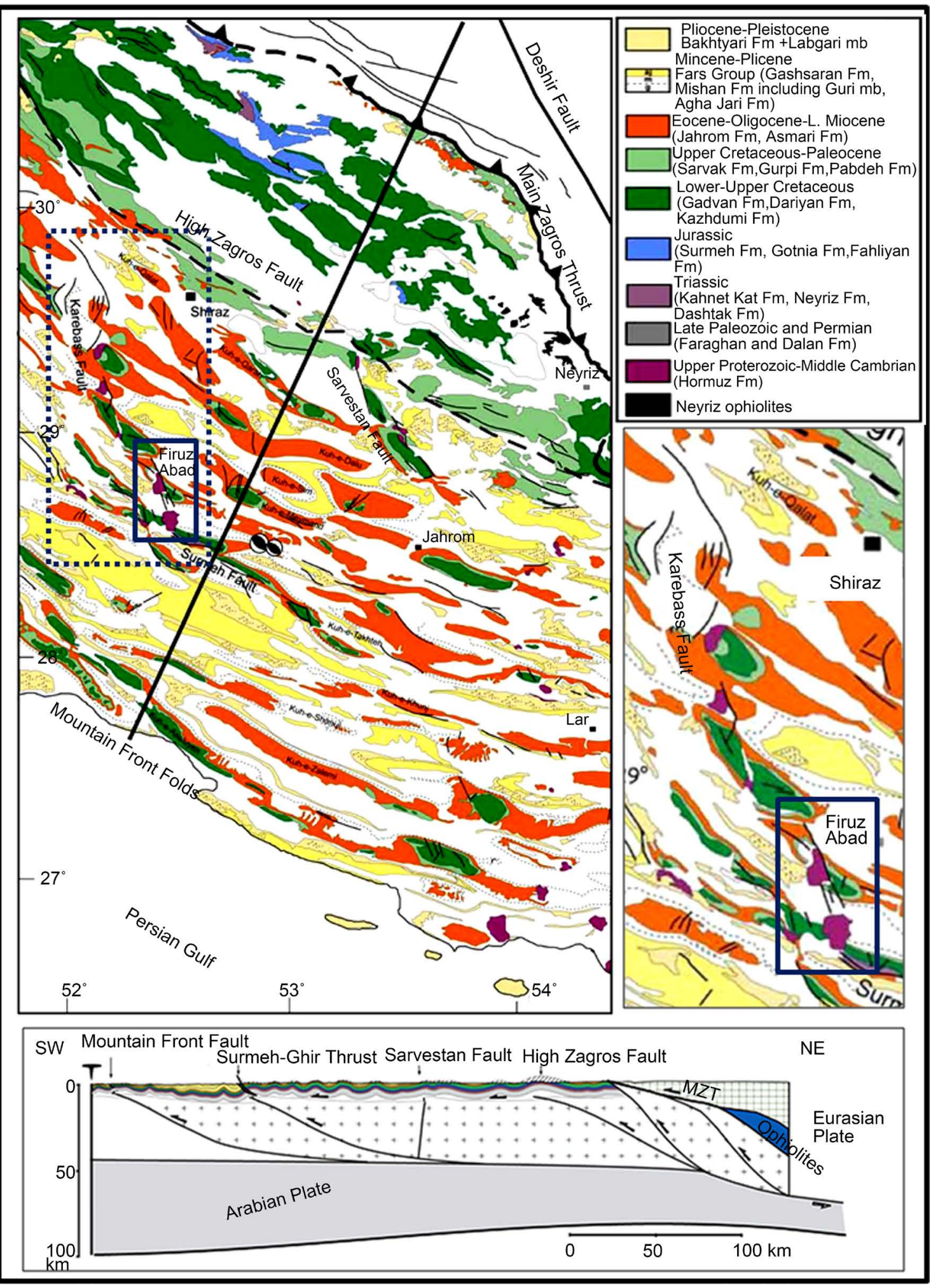

Figure 3. Geological map of the Fars Geological map of the Fars based on a compilation of geological 1:250,000 and 1:100,000 scale maps from the National Iranian Oil Company. The Imbricate Zone (High Zagros) north of the High Zagros Fault is characterized by the lack of Oligo iocene deposits which contrast with the Zagros Folded Belt to the south. The anticlines and the major transverse strike slip faults are depicted. A crustal-scale section of the Zagros Simply Folded Belt. MZT-Main Zagros Thrust. Fault Zone of Korebas, salt domes (purple) associated with it and study area (dark blue rectangle) on the map is clear. 


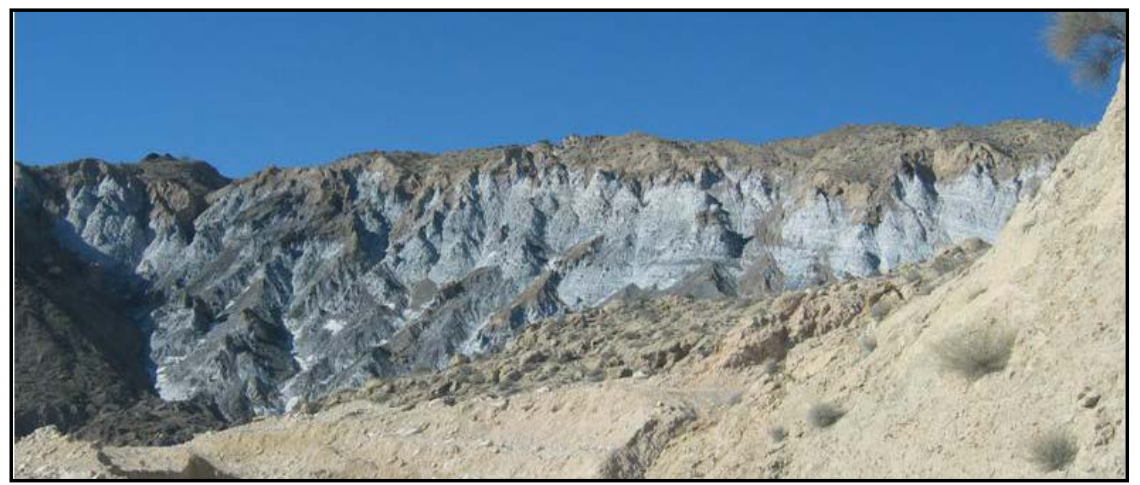

Figure 4. Close-up of Mangeark salt dome-see the East side.

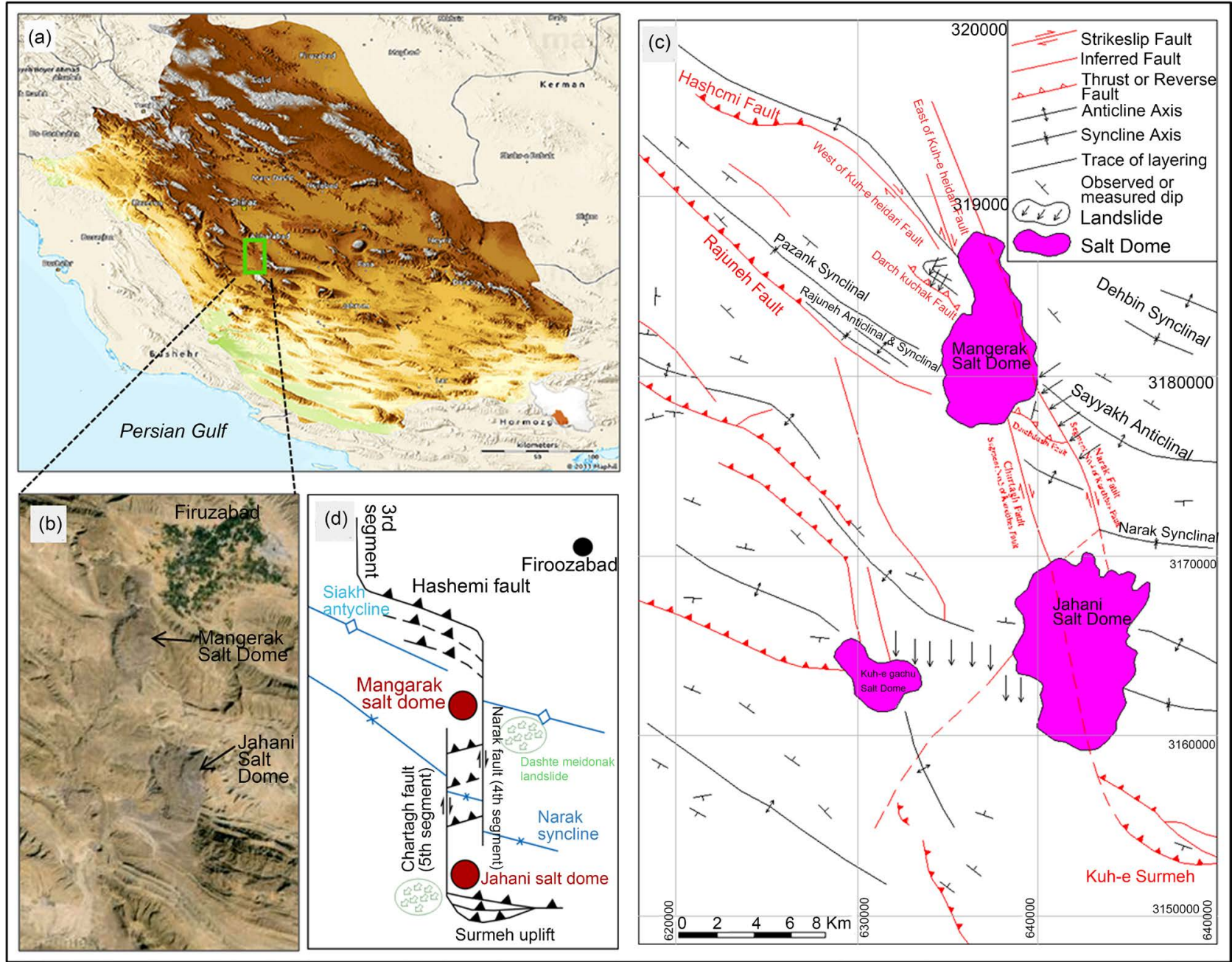

Figure 5. The structural map of the study area. (a): Map of unevenness in Fars province and the study area. (b): ETM map of the study area where the Mangerak salt dome is shown on it. (c): structural map of the study area and (d): Schematic model of how the structures in the studied area and sector-peripherally related.

on the basement [17]. Iran's Zagros belt, in terms of zoning tectonic, morphology and intensity of deformation are divided into three structural parts of parallel to the belt that are separated from one another by the main fault zone trending NW-SE [18]. These zones are respectively from the northeast to the southwest 

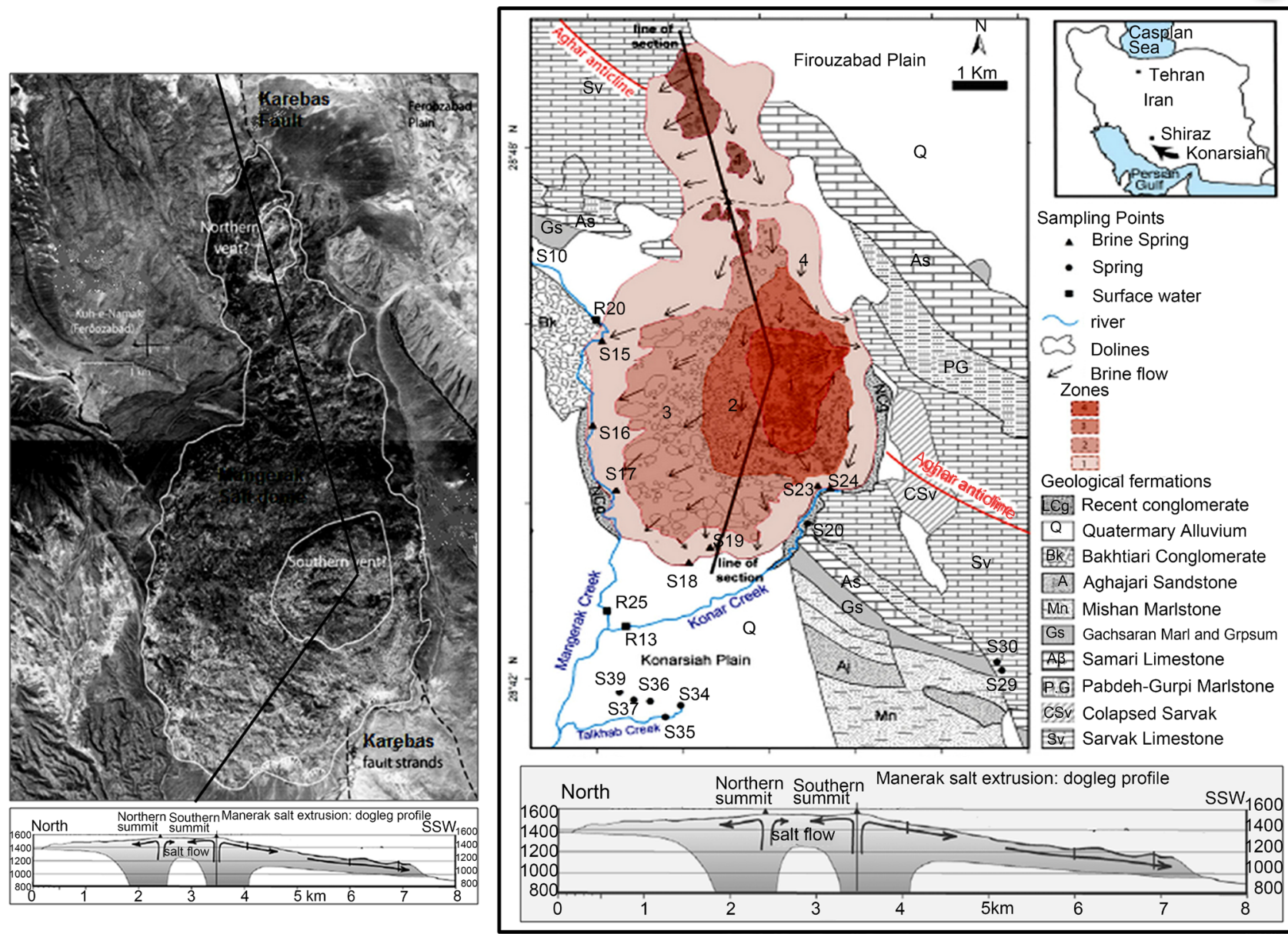

Figure 6. Geological map of Mangerak diapir and its position in the Korebas transtentional zone. According to the direction of salt movement, it seems to be a twin diapir and has a double chimney. The figure below, Dogleg profile along the path shown on map.

include squamous Zagros belt, Zagros simply folded belt and deep zones of Zagros (Figure 2). Simply folded belt is divided from the northwest to the southeast, in Lorestan, Ferobar Dezful and Fars, according to facies changes and psychological of cover sequence and tectono sedimentary evolution, respectively that is separated from each other by the fault zones NS and EW (Figure 2) [19]. Fars area is divided into four sectors, including domestic Fars, Coastal Fars, and Fars to the approximation of the Coast and the canvas Bandar Abbas (Figure 2). Studied area is located on simply folded belt and in the Fars region. In the northwestern part of the Fars region, there are several fault zones trending roughly north south and North East-South West, which in line with the number of them, salt diapirs series of Hormuz is exposed. These faults include Kazeron right fault zones, Korebas, Bahar, Sabz Poushan, Sarvestan and Nezamabad left fault zone (Figure 2). The study area includes Mangarek salt diapir in line with a part of the Korebas fault zone (Figure 3).

\section{The Main Structural Elements}

Due to the structural map of the study area (Figure 5), the most important 
structural problem in the study area is a Mangarek salt dome. This dome has surface expose along the Sayakh anticline axis and at the site of Korebas fault. Korebas fault with a length of $160 \mathrm{~km}$ is located in $65 \mathrm{~km}$ east of the Kazeron active fault and $35 \mathrm{~km}$ West of Shiraz. The Rastalghaz right slip fault is with trending NS that the fault caused the displacement and elongation of at least 10 kilometers around the folds of the region. During the fault, which is composed of at least 6 fault segments, five large salt domes are exposed [20]. South-piece Bas fault by turning to the East Side, creates Sorme thrusting. The fourth part of the fault, along with 348 master degrees, and the length of $30 \mathrm{~km}$, are located within $15 \mathrm{~km}$ of map and begin from $15 \mathrm{~km}$ West Firozabad to cause right separation more than $6 \mathrm{~km}$ in Sayakh anticline. This fault segment cuts the Sayakh anticline axis and makes the salt (Mangerak dome) reach the surface at the core of the anticline [21] [22] [23].

The Sayakh anticline axis is like structures dominate of the Zagros North West-South East. Layering dip of the northeastern edge of the study area is the average of about 40 degrees, but in the anticline hinge, low slope to flat layers are created the box folded form. South-West fault has more than the average slope of the ridge edge of the Northeast and in some parts, layers are vertical. Therefore, an anticline structure in the study area has vergence to the South West which is consistent with the general pattern of folding in the Zagros region. Korebas fault has replaced the anticline axis to $6 \mathrm{~km}$ and has caused salt dome of Mangerek in the anticline axis. Apart from Bas fault, another fault trending North East-South West in Nodal cross, has cut the anticline, and along with Bas fault has created the conjugate anticline fault forms. In continuation of the Southeast trend, an anticline is called Aghar and gas wells 1 to 3 of Aghar are in operation at this anticline.

\subsection{Structures Related to Dome formation}

Salt domes create various factors in the placement and climb due to gravitational instability, low density layers (salt) and climbing salts, which are covered by rocks with higher density and due to buoyancy force [24]. There are salt domes involved, which consist of floating force, differential loading, overburden folding due to compression and stretching in the overburden are the most important factors to the rise of diapirs [25]. In addition, after rising salt dome, structural changes will be formed in the relationship to it which is then discussed.

Peripheral or marginal reverse faults are included structures that have been observed in the study area at some points and as shown in Figure 5, these faults adherence clearly from the contact border of the dome with adjacent layers. Another clear feature that can be seen abundantly in the region is changing the angle of the slope and the slope layers and thinning and changes in their thickness, on the border between the Dome and its surrounding sediments. In this case, it can be created because of an uplift effect of the salt dome and reverse faults (Figure 7) and strike-slip.

Folds in connection with marginal reverse faults are observed within this limit. 
In Figure 8, the image of a fold in relation to the fault is displayed. This fold axis was in parallel to marginal reverse faults and its southern edge is in contact with these faults and has a returned mode. Folding mechanism is the flow mechanism and is composed in the gypsum layers that have plastic deformation properties. Layer thickness is higher in the hinge area more than the edges and the reason is gypsum flowing from high-pressure areas (edges) to the low pressure areas (hinge).

\subsection{Neotectonics Works of Dome Formation}

\section{A. Salt dome uplift}

In relation to the salt dome, activity of Mangarek, dolomitic limestone pebbles, bituminous dolomites, sandstone parts and other belong to Hormuz salt formation that reach the surface with the dome, are in Bakhtiari Formation in the South West of the dome and the density of pebbles increases toward the dome. This indicates that the peak of the dome was at the time that causes reaching the dome to surface and before, it probably has been a buried dome.

In the North West of the dome, sandstone sediments of Bakhtiari Formation, with closing to the dome, it becomes a conglomerate and the whole Bakhtiari formation will be thin, that reflects uprising or dome exposed at the time.

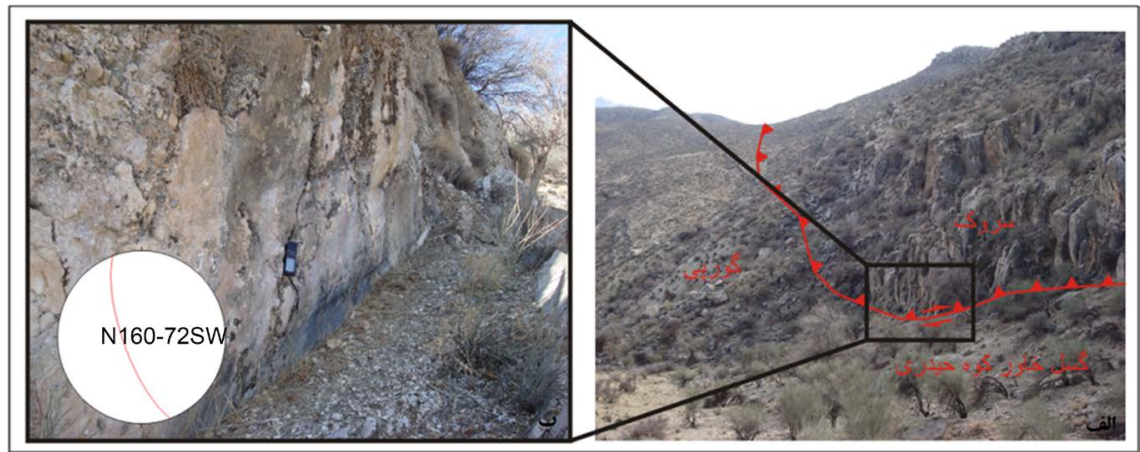

Figure 7. East dextral strike-slip fault Heydari mountains with steep to the north east look to the South East (Right), clear wall of the East fault Heidari Mountain that is exposed in many places and the fault location on Sterionet (Left).

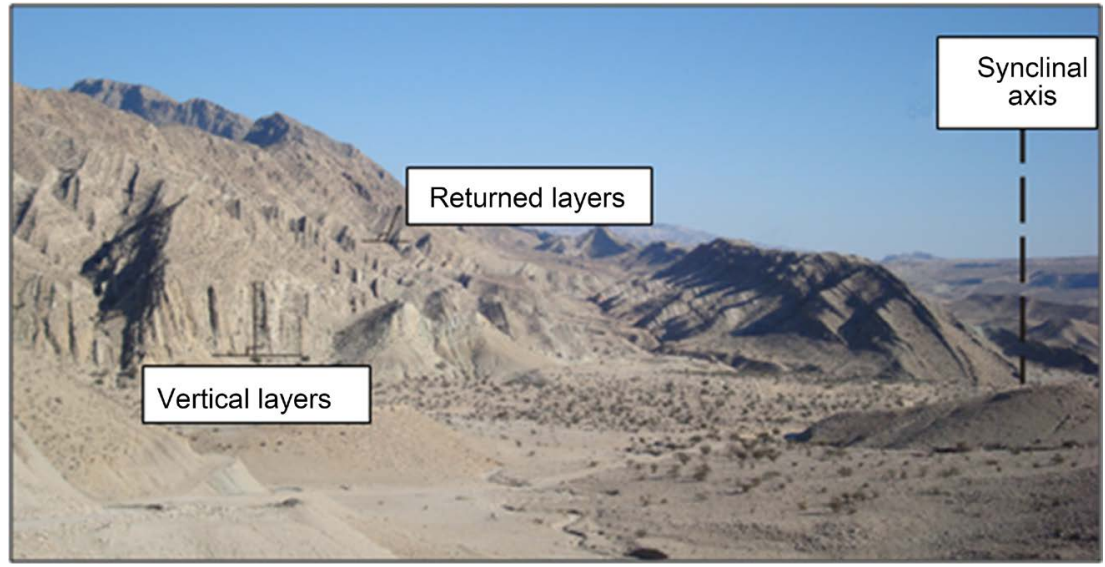

Figure 8. Narak syncline with the upright axis surface-Look to the East. 
B. Quaternary movements

Folding and tilting in relatively thick layers of Bakhtiari Formation and Quaternary (Figure 9) can be seen in many parts of the study area. On the Chartagh fault wall (see Figure 4), Quaternary conglomerates have large slope. This fault in the form of strike-slip has moved waterways and other complications. These replacements differ from 2.5 - 3 meters to 10 - 20 meters and reach to 45 meters [26]. The performance of this fault causes deformation in the Bakhtiari conglomerate Formation. The Bakhtiari conglomerate in the western fault block has steep, sometimes vertical and even turned.

\section{Morphotectonic works}

The Mangarek salt dome climb has a significant effect on Morphotectonic on the Firozabad River (Figure 10). River in this area is approximately to the North West-southeast. The river meanders by approaching the salt dome, and in the southern part of the dome, and after passing through it, changes to the south and channel pattern has changed. In the middle of two salt dome of Mangerak and global, also Firozabad River with an East-West has an intense meandering pattern, it suggests that salt dome of Mangarek, today, is enabled, and is rising and as a result, this ascent height in this section, gradually increase and by changing the level of the river, the river immigrated to the south that traces of the old channel of the river are detectable both in the desert and the images of remote sensing (Figure 10).

\section{Karst Works Related to Salt Dome}

Karst works related to the salt dome of Mangarek include Doline, sinkholes, and cavern. In Figure 11, an example of these sinkholes can be seen. These sinkholes have oval or circular shapes and the slope of its walls are steep and due to the roof collapses, the voids near the surface or falling of karst springs will cause

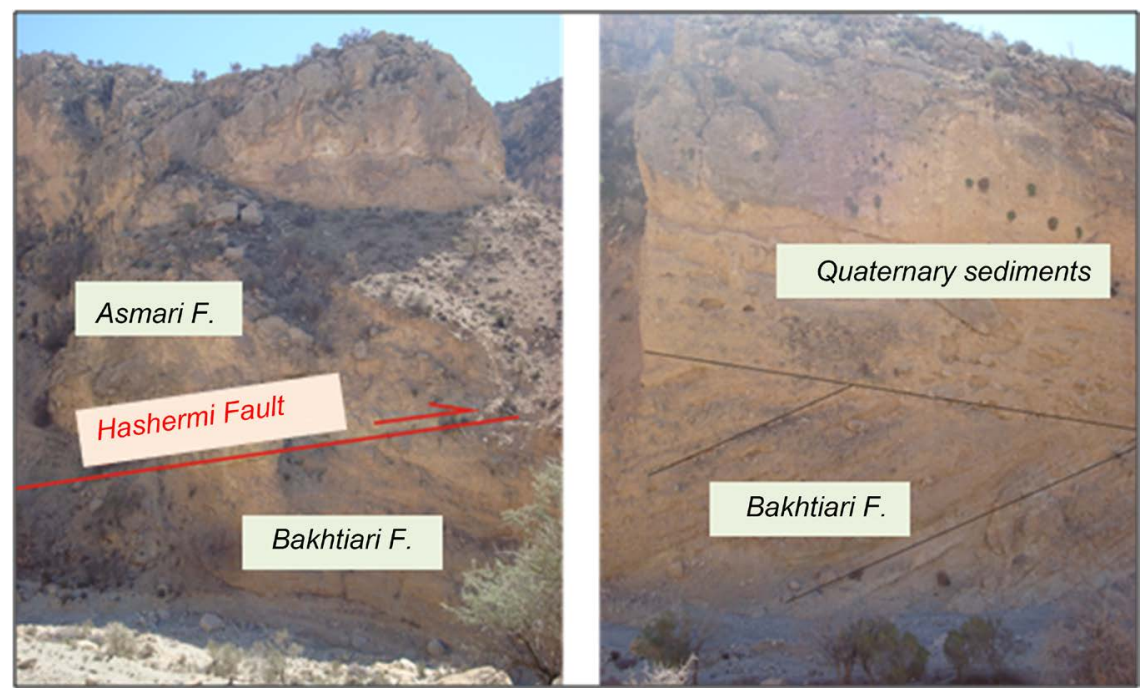

Figure 9. (Right) Angular unconformity between the conglomerate of Bakhtiari Formation and newer clastic sediments of Quaternary. (Left) Asmari formation drifting on Bakhtiari Formation conglomerate by Hahsmei faults, performance-look to the East. 


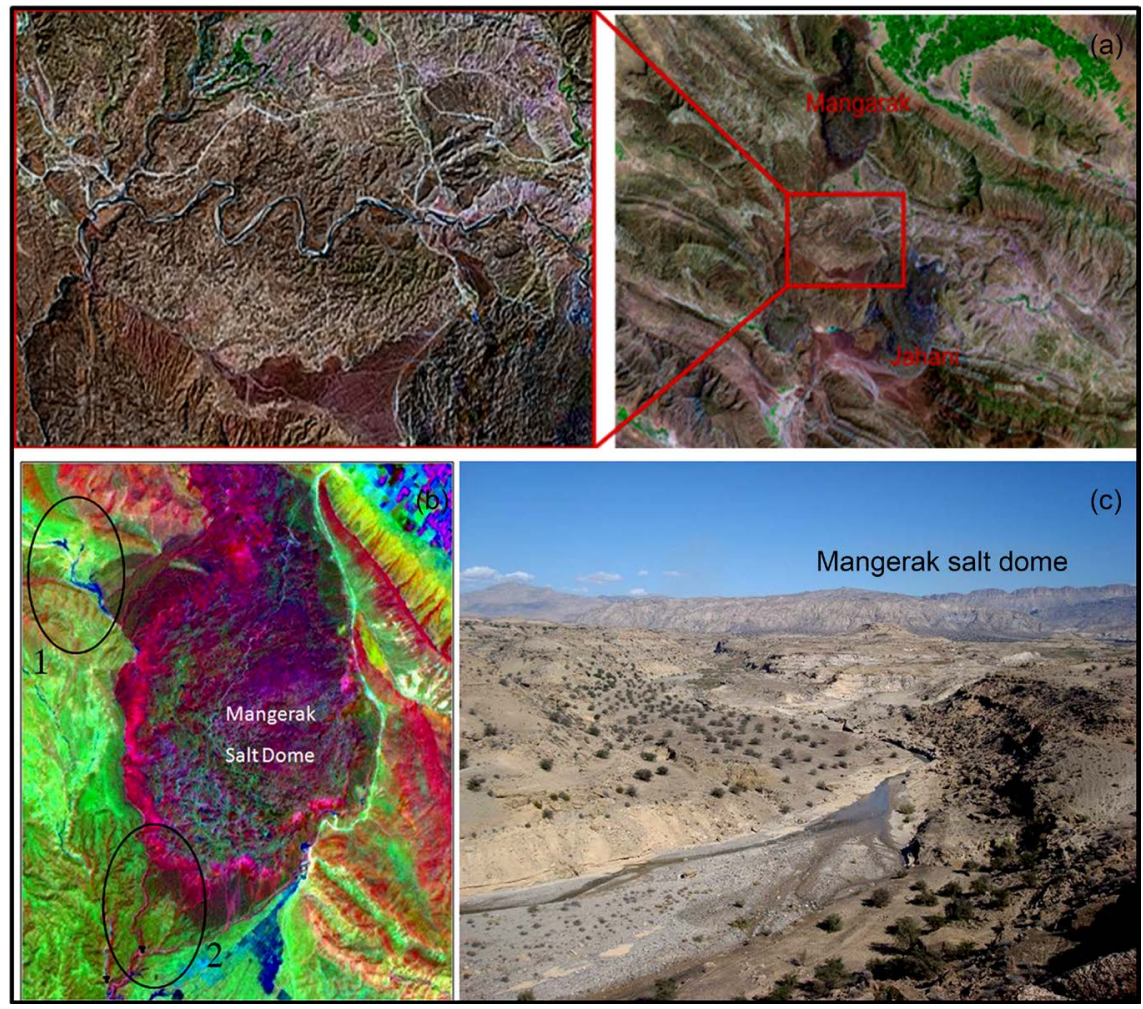

Figure 10. (a) Position of Firozabad river compared to Mangerak and global salt dome and creating a meandering state in satellite image; (b) crossing the Firozabad river from the northwest of the Mangerak dome (1) and crossing the same river from the south of the same dome and change the pattern stream of it (2); (c) the Firozabad river in the area 1 and Figure $b$ and cut walls in Bakhtiari formation by the Firozabad river. Look East.
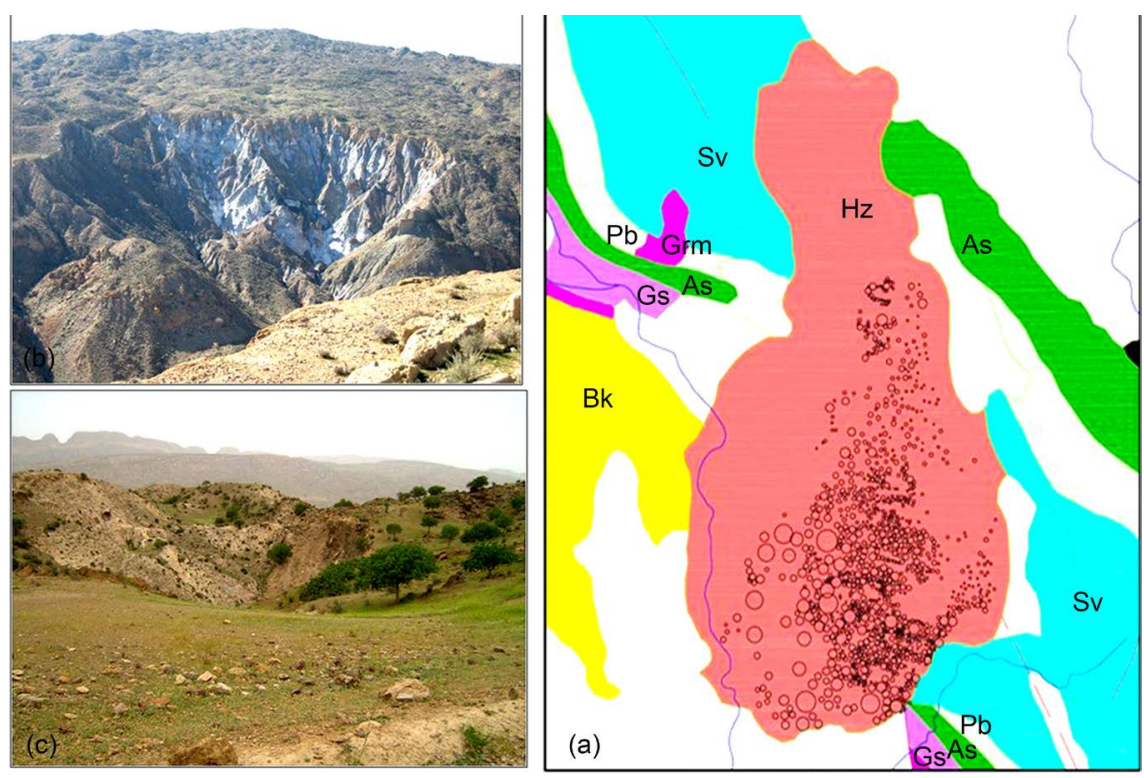

Figure 11. (a) Location map of sinkholes and Devlin on Mangerak dome body is shown with black circles. (b) and (c) images of karst sinkholes in Mangerak salt dome.

[27]. About 2600 Devlin and sinkholes can be separated in diapir Mangarek (Figure 11). 


\subsection{Layering Analysis of Field Data}

By field measuring, position change of layering was studied. Stereograms of layering in different locations of the area around the salt dome Mangarek is shown in Figure 12 that shows along layers are clearly compliant with the contact border of salt dome with layers surrounding it so that their dominant process is aligned with the boundaries of the salt dome in most sectors. The angle of layers slope increases towards the salt dome and across the border in contact with the dome, they nearly vertical slope in some places will be returned.

\subsection{Data Analysis Related to a Regional Unconformity System}

During field visits carried out, with measurement discontinuities existing system and by drawing the related rose plots, the discontinuities are studied. In Figure 13, rose diagrams related to fractures of the entire region is shown. The two categories of fractures within the area can be distinguished. One of these fracture systems have a NE-SW trend and form the region's major fractures. The other category has the trendy north to northeast and south to southwest.

\section{Analytical Modeling}

Given that, the data necessary for numerical simulation in this study was not enough, (lack of landing data to prepare the pattern and cutting simulation and

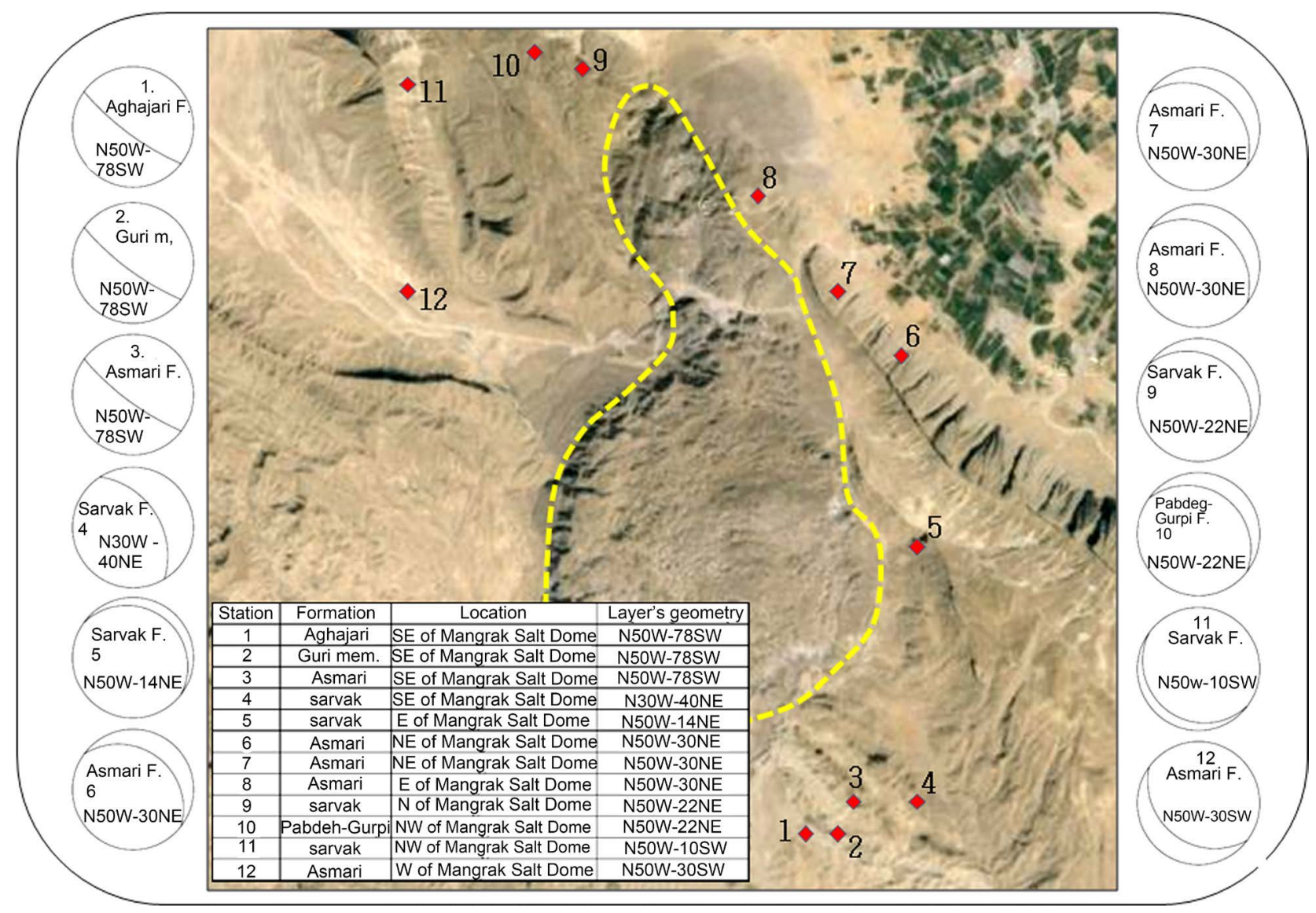

Figure 12. Stereograms related to layering status around Mangarek dome. 


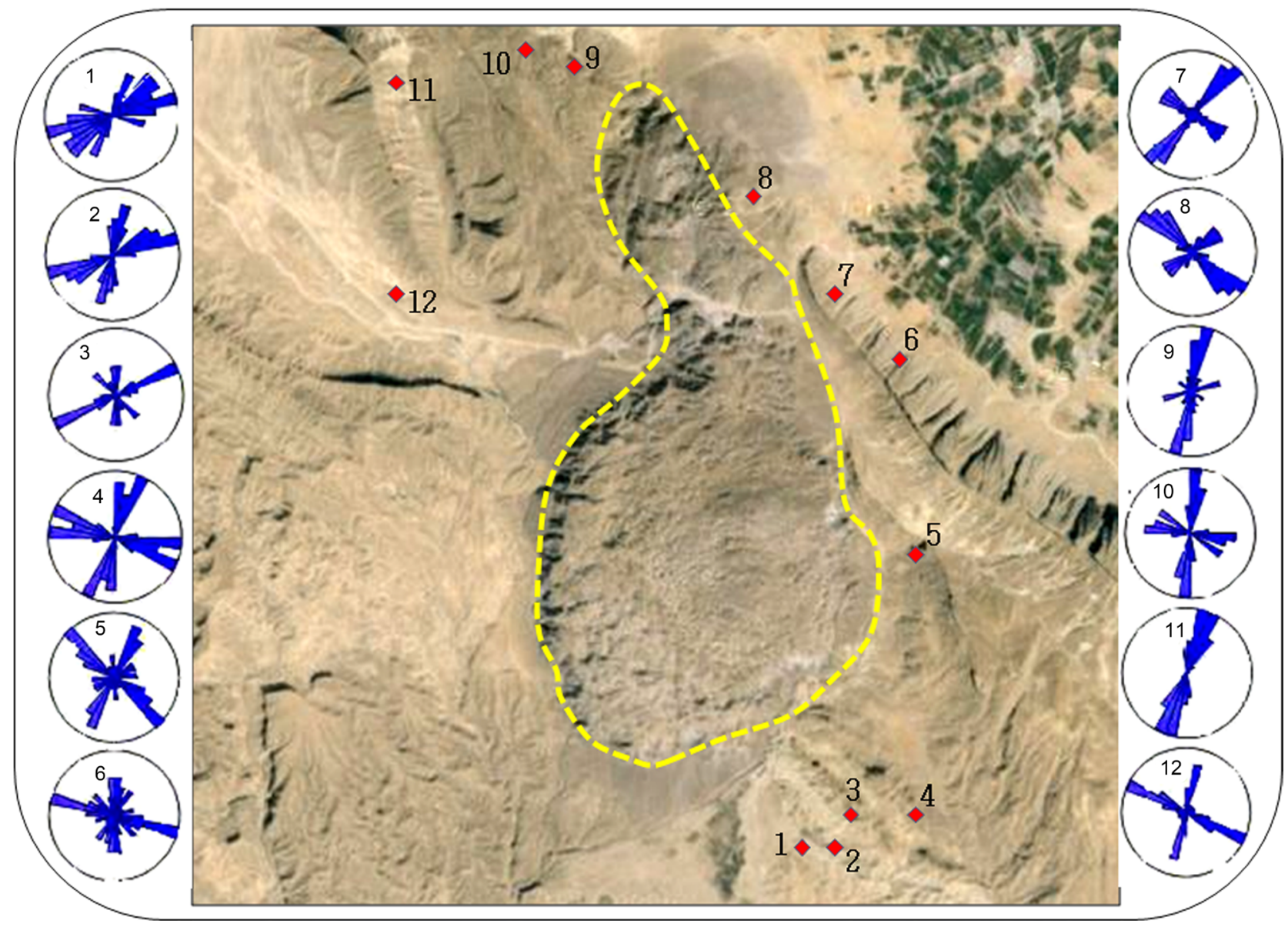

Figure 13. Red Rose Diagram of fractures around the Mangarek dome.

for the preparation of a three-dimensional model and the lack of project finance, to carry out a series of trials, to determine the geomechanical parameters of salt and enclosing rocks, including Young and Poisson coefficients and internal friction angle), we have forced to do the analytical modeling. To analyze the model, for diapirism salt, a model must be chosen that will be compatible with the geological conditions of formations and properties of rock salt and enclosing rocks and at the same time, given the information contained in this research, this model will be run. In this regard, linear model and double layers that are selected to maintain the continuity of materials, boundary conditions described below are taken into account [28] [29]. If two layers that are considered the bottom layer is salt and the top layer is sediment overburden, for salt borders and $\mathrm{Mi}$ ocene sediments, by considering boundary conditions, salt stone movement is considered in fluid with a viscosity $(\mu)$ that the approaches infinity, that movement is expressed with below differential equation:

$$
(\partial u / \partial x)+(\partial v / \partial y)=0
$$

In this equation, the first sentence is the fluid flow rate in order to $\mathrm{x}$ and the second sentence is the fluid flow rate in order to $y$. If the $x$-axis is horizontal and we show the salt movement flow line equation with $\psi$, then for speed equations in the direction $x$ and $y$ we have: 


$$
\begin{array}{r}
u=\partial \psi / \partial y \\
V=\partial \psi / \partial X
\end{array}
$$

If we replace the Equation (2) and Equation (3) in Equation (1) and place them in the fluid pressure equation (Equation (4)), its display with differential equations will be the Equation (5).

$$
P=p-\rho g h
$$

In this regard, $-P$ is fluid pressure, $-p$ is atmospheric pressure and $-\rho g h$ is potential energy.

$$
\begin{aligned}
& p \rightarrow N / m^{2} ; \rho \rightarrow g r / c m^{3} ; g \rightarrow m / s^{2} ; h \rightarrow m \\
& (-\partial P / \partial y)+\mu\left(\left(\partial v^{2} / \partial x^{2}\right)+\left(\partial v^{2} / \partial y^{2}\right)\right)=0
\end{aligned}
$$

In this case, we have:

$$
\begin{aligned}
& (-\partial p / \partial x)+\mu\left(\left(\partial \psi^{3} / \partial x^{2} \partial y\right)+\left(\partial \psi^{3} / \partial y^{3}\right)\right)=0 \\
& (-\partial p / \partial y)+\mu\left(\left(\partial \psi^{3} / \partial x^{2}\right)+\left(\partial \psi^{3} / \partial y^{2} \partial x\right)\right)=0
\end{aligned}
$$

By solving this differential equation, we have:

$$
\left(\partial \psi^{4} / \partial x^{4}\right)+2\left(\partial \psi^{4} / \partial x^{2} \partial y^{2}\right)+\left(\partial \psi^{4} / \partial y^{4}\right)=0
$$

The equation is called Biharmonic equivalence and simply has been expressed as follows.

$$
\nabla^{4} \psi=0
$$

The linear equation of flow $(\psi)$ sine function is as follows (Equation (8))

$$
\psi=\sin (2 \pi / \lambda) \cdot y_{(y)}
$$

In this equation $-\lambda$ is mentioned harmonic wavelength, and $\mathrm{y}$ is a function of $y$, namely:

$$
\psi=\sin \frac{2 \pi X}{\lambda}\left(A e \frac{-2 \pi y}{\lambda}+B y e \frac{-2 \pi y}{\lambda}+\operatorname{Co} \frac{2 \pi y}{\lambda}+D y e \frac{2 \pi y}{\lambda}\right)
$$

In this regard, $A, B, C$ and $D$ are contract constants.

Equation (8) is Fluid equation of motion and for this reason; the sinusoidal nature of this equation is that salt is increasing in wave and harmony. For a simple model of salt bilayers and overburden rocks, will be something like Figure 14 . If we write the equations of flow, $\psi_{1}$ is solved for Miocene sediments and $\psi_{2}$ is solved for the salt.

$$
\begin{aligned}
& \psi_{1}=\sin \frac{-2 \pi x}{\lambda}\left(A_{1} \cosh \frac{2 \pi y}{\lambda}+B_{1} \sinh \frac{-2 \pi y}{\lambda}+C_{1} \cosh \frac{2 \pi y}{\lambda}+D_{1} \sinh \frac{2 \pi y}{\lambda}\right) \\
& \psi_{2}=\sin \frac{2 \pi x}{\lambda}\left(A_{2} \cosh \frac{2 \pi y}{\lambda}+B_{2} \sinh \frac{-2 \pi y}{\lambda}+C_{2} \cosh \frac{2 \pi y}{\lambda}+D_{2} \sinh \frac{2 \pi y}{\lambda}\right)
\end{aligned}
$$

When moving rock salt began, boundary layers will be withdrawn from the horizontal, which ranges boundary of layers will be stated $\omega$ that in this case, if we derived $\psi_{1}$ in terms of $X$, we have:

$$
\left(\partial \psi_{1} / \partial x\right) \cdot \cos (\partial \omega / \partial t)=(2 \pi A / \lambda) \cdot \cos (2 \pi x / \lambda)
$$




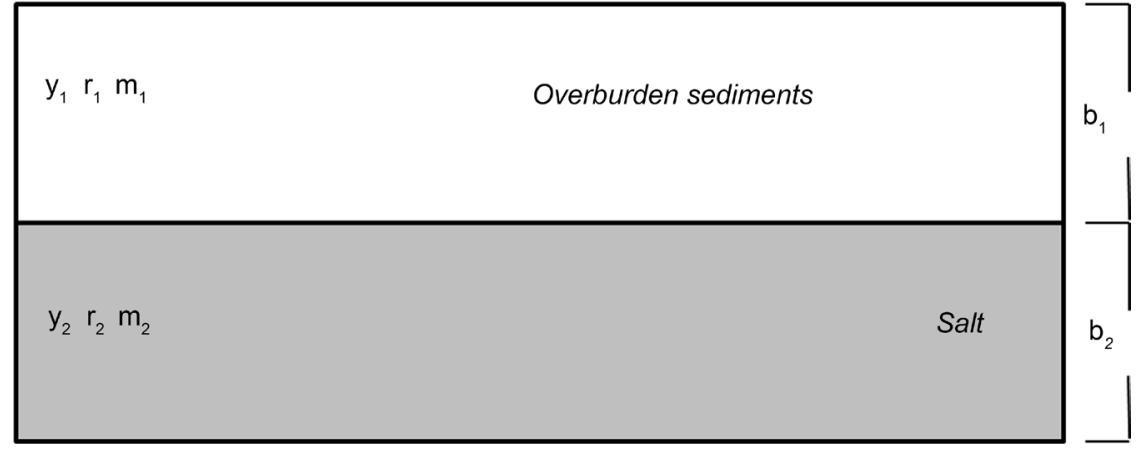

Figure 14. Simple two layers model of salt and overburden rocks.

When salt flows up, boundary layers will start to interfere that is because, the performance of buoyancy force (buoyancy) that this issue is instability (Rayleigh-Taylor). This buoyancy force is stated with below equation:

$$
F=\left(f_{1}-f_{2}\right)-g m
$$

In this equation, $(g r) m$ is overburden mass, $\left(\mathrm{m} / \mathrm{s}^{2}\right) g$ is acceleration of gravity, $\left(\mathrm{N} / \mathrm{m}^{2}\right) f_{1}$ is force from the salt to overburden and $\left(\mathrm{m} / \mathrm{s}^{2}\right) f_{2}$ is the force from overburden to the salt. Salt movement and layers boundary interaction is the start of Diapirism that if we want to examine the salt movement range and its wavelength, for the wavelengths, we have:

$$
\omega=\omega_{0}(2 \pi x / \lambda)
$$

With the arrival of buoyancy force into the differential equations and then deriving from this relationship to time, we have:

$$
\frac{\partial \omega}{\partial t}=\frac{\left(f_{1}-f_{2}\right) g h}{4 \mu} \cdot \frac{\left[\left(\frac{\lambda}{2 \pi b}\right)^{2} \operatorname{tgh}^{2} \frac{2 \pi b}{\lambda}-\frac{1}{\sinh (2 \pi b / \lambda) \cosh (2 \pi b / \lambda)}\right]}{\left[\left(\frac{\lambda}{2 \pi b}\right)+\frac{1}{\sinh (2 \pi b / \lambda) \cosh (2 \pi b / \lambda)}\right]} \cdot \omega
$$

The result of this differential equation is in the following equation:

$$
\omega=\omega_{0} e_{a}^{t / \tau}
$$

In this equation, the peak has a maximum and it is incremental, which means that, salt is growing or diapirism will continue to grow after the beginning of growth and will not stop. $\tau_{a}$ is a constant that advocates to the geological zones and time growth (grow time) is diapered and is expressed in the form:

$$
x \tau_{a}=\frac{4 \mu}{(f 1-f 2) g h} \cdot \frac{\left(\frac{\lambda}{2 \pi b}+\frac{1}{\sinh (2 \pi b / \lambda) \cosh (2 \pi b / \lambda)}\right)}{\left[\left(\frac{\lambda}{2 \pi b}\right)^{2} \operatorname{tgh} \frac{2 \pi b}{\lambda}-\frac{1}{\sinh (2 \pi b / \lambda)} \cosh \left(\frac{2 \pi b}{\lambda}\right)\right]}
$$

For numerical and with the placement of value for $2 \pi b / \lambda$ and drawing the plot, concluded that the value $\lambda=2.568 b$ (Equation (16)). Therefore, to put it on the Equation (15), we have:

$$
\tau_{a}=13.04 \mu /\left(\rho_{1}-\rho_{2}\right) g b
$$


In this equation, $\mathrm{b}(\mathrm{m})$ is the thickness of the salt layer, $g\left(\mathrm{~m} / \mathrm{s}^{2}\right)$ is the acceleration of gravity, $\rho_{1}\left(\mathrm{gr} / \mathrm{cm}^{3}\right)$ is density layers of overburden (in this case part of Miocene sandstone layers), $\rho_{2}\left(\mathrm{gr} / \mathrm{cm}^{3}\right)$ is salt density, $\mu$ (pas.s) is salt viscosity and $\tau_{a}$ is the salt dome time formation. In this way, we can calculate other parameters of diapirism with thickness and salt density and overburden rocks.

\section{The Results of the Model}

In this section, we tried to analyze the numbers with the assumptions of placing the numbers and numerical from field information and from the reports and geological maps, possible modes for the diapirism process event will be studied and analyzed modeling.

By substituting $\mu, \rho_{2}, \rho_{1}, g$ values in the Equation (17), the equation related to the salt dome of Mangerak can be achieved. In the first case, in order to relate between the salt dome of Mangerak and the global mountain (which is located 8 $\mathrm{km}$ south of the salt dome Mangerak, Figure 4) the distance between the two domes is considered as the wavelength $(\lambda)$.

Due to the lack of geophysical data in the area, and given the fact that the $\mathrm{Za}$ gros salts were related to Miocene and in the study area the salts have the same age and on the other hand, given the fact that the sedimentary basin that these salts form is the Zagros basin. Thus, the salt layer thickness similar to other areas of the Zagros and the suggested by [30], was considered 200 meters.

In the latter case, the distance between the domes again was assumed as the wavelength. Then, through Equation (16), the layer thickness was calculated. In both cases, the time formation of the salt dome $\left(\tau_{a}\right)$ was calculated by using the Equation (17). Given the irrationality of the results, it was concluded that there is no significant relationship between the thickness of the salt layer and wavelength for salt domes of Mangerak and the global mountain. Therefore, it can be concluded that both domes have not a diapiric relation in terms of formation, but simply in the space between the associated faults have been climbed. As mentioned, KoreBas fault provides a proper weakness for the salt dome climb.

In the third case, again, layer thickness was considered 200 meters, and then by using the Equation (16), the amount $\lambda$ was calculated.

$$
\lambda=2.568 b \quad \lambda=513.6 \mathrm{~m}
$$

In addition, later, with placing the following values in Equation (17), the amount $\tau_{a}$ was calculated.

$$
\begin{array}{ll}
b=200 \mathrm{~m} & \text { Jackson }(1992) \\
\mu=10^{17}-10^{18} \mathrm{pas} \cdot \mathrm{s} & \text { Van Keken et al (1993) } \\
\rho_{1}=2.68 \mathrm{gr} / \mathrm{cm}^{2} & \text { Memarian (1388) } \\
g=9.81 \mathrm{~m} / \mathrm{s}^{2} ; \rho_{2}=2 \mathrm{gr} / \mathrm{cm}^{3} & \\
\tau_{a}=13.04 \mu /\left(\rho_{1}-\rho_{2}\right) \mathrm{gb} & \tau_{a}=30969 \text { years }
\end{array}
$$

Finally, by putting different thicknesses in Equation (18), and obtaining the amount of $\lambda$, the $\lambda$ variation in terms of $b$, will be highlighted. 


$$
\tau_{a}=\frac{4 \mu}{\left(\rho_{1}-\rho_{2}\right) g b} \cdot\left(\frac{2 \pi b}{\lambda}\right)
$$

In this case, time of growth in the Mangarek salt dome was about 31,000 years that in comparison with the observed effects of migration meanders, in the south dome (Firozabad meanders) and the floor up, this time seems reasonable (Figure 15).

\section{Conclusions}

In this study, first, we examine the structure and Morphotectonical range of Mangarek salt dome, a general cognitive was obtained from the expansion status and type of affected structures. Diapirism related structures, in this study, showed that layers of overburden were influenced by diapirism and by influencing diapirism, they climbed upward that the displacement has created the tension in layers, at the top of the dome and normal faults have been created. Whereas, regional tensions have homogeneous state in the region, the expectation was that the normal faults grow with radial pattern. However, this region has a heterogeneous regional tension field, and hence, the pattern of faulting associated with diapirism shows a preferred orientation. It seems that the mobility of these faults is the highest in the center of salt dome and decreases toward the edges of the dome and the depth of these faults is in the penetrating mass margin. Therefore, we can say that the normal faults do not have a lot of control effect in salt dome climbing. However, the marginal reverse faults of salt domes have a lot of roles in salt dome climbing, and have a penetration to high depth (sometimes to the origin of salt formations). Therefore, they have an importance in modeling and preparing geological slices. In relation with Mangarek salt dome climbing mechanisms, three general steps are resulted:

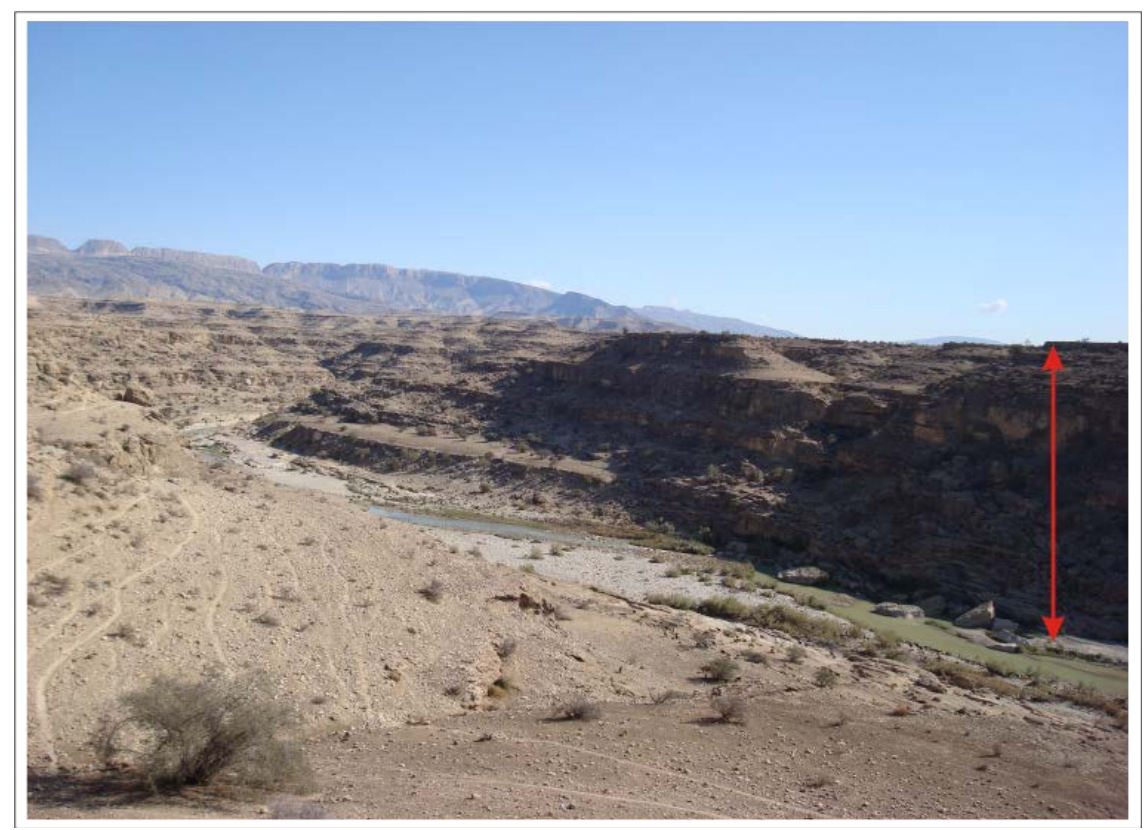

Figure 15. Creating high walls due to flooring of Firozabad River, looking north. 
Basin formation, as a result of tectonic regime governs in the region, and the more extension of these structures along with the NW-SE, shows the dominance and greater perpendicular tension to this trend that is consistent with the tension system caused by the collision of the Arabian plate with Iran.

Also, at the time of emplacement of the salt dome, it should be noted that Mangaerk salt dome existed pre-deformation of Zagros Basin and possibly, at least it was exposed in the late Paleogene sea and Neogene as an island (such as salt dome islands of Persian Gulf today). The dome is active and now, is going up. To declare the rise time, due to lack of adequate field evidence, with the help of modeling in this study, the time was estimated 31,000 years ago.

Neotectonic evidence available also indicates the continued growth of the dome. On the south and southwest of the Mangerak salt dome, young alluvial river Firozabad has slope from the ascent, and on the other hand, climbing performance of salt dome has caused to bypass the salt dome river and create a wide Mander. The salt dome climb, and gradually increase the height of the southern part of the salt dome has caused, Firozabad River gradually migrates by forming the first Mander and new Mandrhay position will be displaced and emigrated as well from the salt dome, to the south.

\section{References}

[1] Atlantic Avenues of Iran, Design and Preparation of Geographical Lithography, Scale 000000: 1-2009. Journal of Geology.

[2] Sedaghat, M. and Dabayat Nejad, A. (1996) Geological Map 1:100,000 Geological Survey and Mineral Exploration Country. Farashband Press, Iran.

[3] Bahroodi, A. (2003) The Effect of Mechanical Characteristics of Basal Decollement and Basement Structures on Deformation of the Zagros Basin. Geological Study, Iran.

[4] Bahroodi, A. and Koyi, H.A. (2003) Effect of Spatial Distribution of Hormuz Salt on Deformation Style in the Zagros Fold and Thrust Belt: An Analogue Modelling Approach. Journal of the Geological Society London, 160, 719. https://doi.org/10.1144/0016-764902-135

[5] Berberian, M. (1995) Master "Blind" Thrust Faults Hidden under the Zagros Folds: Active Basement Tectonics and Surface Tectonics Surface Morphotectonics. Tectonophysics, 241, 193-224. https://doi.org/10.1016/0040-1951(94)00185-C

[6] Berberian, M. and King, G.C.P. (1981) Towards a Paleogeography and Tectonic Evolution of Iran. Canadian Journal of Earth Sciences, 18, 210-265. https://doi.org/10.1139/e81-019

[7] Edgell, H.S. (1996) Salt Tectonic in the Persian Gulf Basin. The Geological Society.

[8] Molinaro, M., Guezou, J.C., Leturmy, P., Eshraghi, S.A. and Frizon de Lamotte, D. (2004) The Origin of Changes in Structural Style across the Bandar Abbas Syntaxis, SE Zagros (Iran). Marine and Petroleum Geology, 21, 735-752. https://doi.org/10.1016/j.marpetgeo.2004.04.001

[9] Sherkati, S. and Letouzey, J. (2004) Variation of Structural Style and Basin Evolution in the Central Zagros (Izeh Zone and Dezful Embayment), Iran. Marine and Petroleum Geology, 21, 535-554. https://doi.org/10.1016/j.marpetgeo.2004.01.007

[10] Walpersdorf, A., Hatzeld, D., Nankali, H., Tavakoli, F., Nilforoushan, F., Tatar, M., Vernant, P., Chery, J. and Masson, F. (2007) Dofferece in GPS Deformation Pattern 
and Central Zagros (Iran), 2005. Geophisical Journal International.

[11] Oveisi, B. (2010) Rares and Processes of Active Folding Evidenced by Pleistocene Terraces at the Central Zagros Front (Iran). Thrust Belts and Foreland Basins, Springer.

[12] Bordenave, M.L. (2002) The Middle Cretaceous to Early Miocene Petroleum System in the Zagros Domain of Iran, and Its Prospect Evolution.

[13] Koyi, H. (1988) Experimental Modeling of Role of Gravity and Lateral Shortening in Zagros Mountain Belt. AAPG Bulletin, 72, 1381-1394.

[14] Lacombe, O., Mouthereau, F., Kargar, S. and Meyer, B. (2006) Late Cenozoic and Modern Stress Fields in the Western Fars (Iran): Implication for the Tectonic and Kinematic Evolution of Central Zagros. Tectonics, 25, TC1003. https://doi.org/10.1029/2005tc001831

[15] Berberian, M. (1994) Master Blind Thrust Faults Hidden under the Zagros Folds: Active Basement Tectonics and Surface Morphotectonics. Tectonophysics, 241, 193-224. https://doi.org/10.1016/0040-1951(94)00185-C

[16] Mouthereau, F., Lacombe, O. and Meyer, B. (2005) The Zagros Folded Belt (Fars, Iran): Constraints from Topography and Critical Wedge Modeling. Geophysical Journal International, 165, 336-356. https://doi.org/10.1111/j.1365-246X.2006.02855.x

[17] Snyder, D.B. and Barazangi, M. (1986) Deep Crustal Structure and Flexure of the Arabian Plate Beneath the Zagros Collisional Mountain Belt as Inferred from Gravity Observations. Tectonics, 5, 361-373. https://doi.org/10.1029/TC005i003p00361

[18] Talbot, C.J. (1998) Extrusions of Hormuz Salt in Iran. The Geological Society, 143, 315-334. https://doi.org/10.1144/GSL.SP.1998.143.01.21

[19] Talbot, C., Medvedev, S., Alavi, M., Shahrivar, H. and Heidari, E. (2007) Salt Extrusion at Kuh-e-Jahani, Iran, from June 1994 to November 1997. The Geological Society, 174, 93-110. https://doi.org/10.1144/GSL.SP.1999.174.01.06

[20] Tatar, M., Hatzfeld, D. and Ghafory-Ashtiany, M. (2003) Tectonics of the Central Zagros (Iran) Deduced from Microearthquake Seismicity. Geophysical Journal International, 156, 255-266. https://doi.org/10.1111/j.1365-246X.2003.02145.x

[21] Talebian, M. (2003) A Reappralisal of Earthquake Focal Mechanisms and Active Shortening in the Zagros Mountains of Iran. Geophysical Journal International, 156, 506-526. https://doi.org/10.1111/j.1365-246X.2004.02092.x

[22] Verges, J., Grelaud, S., Karpuz, R., Osthus, H., Nalpas, T., Shape, I. and Guadarzi, H. (2002) Structure of the Zagros Mountain front (Selurestan< Iran): Controls from Multiple Detachment Levels.

[23] Evans, D.J. and Chadwick, R.A. (2009) Underground Gas Storage: Worldwide Experiences and Future Development in the UK and Europe. The Geological Society, 313, 215-224.

[24] Jackson, J.A. (1992) Partitioning of Strike-Slip and Convergentmotion between Eurasia and Arabia in Eastern Turkey and Caucasus. Journal of Geophysical Research, 97, 12471-12479. https://doi.org/10.1029/92JB00944

[25] Koyi, H.A. and Peterson, K. (1993) The Influence of Basement Faults on the Development of Salt Structures in the Danish Basin. Marine and Petroleum Geology, 10 , 82-94. https://doi.org/10.1016/0264-8172(93)90015-K

[26] Ramsay, J.G. and Huber, M.I. (1987) The Techniques of Modern Structural Geology, Vol. 2: Folds and Fractures. Pergamon Press, London.

[27] Suppe, J. (1984) Principles of Structural Geology, Department of Geological and Geophysical Sciences. Princeton University Press, Princeton. 
[28] Twiss, R.J. and Moores, E.M. (2007) Structural Geology. WH Freeman and Company, New York, $532 \mathrm{p}$.

[29] Waltham, D. (1996) Why Does Salt Start to Move? Journal of Tectonophysics, 282, 117-128. https://doi.org/10.1016/S0040-1951(97)00215-1

[30] Turcotte, D.L. and Schubert, G. (2002) Geodynamics. 2nd Edition, Cambridge University Press, Cambridge, 456 p. https://doi.org/10.1017/CBO9780511807442

\section{Scientific Research Publishing}

Submit or recommend next manuscript to SCIRP and we will provide best service for you:

Accepting pre-submission inquiries through Email, Facebook, LinkedIn, Twitter, etc. A wide selection of journals (inclusive of 9 subjects, more than 200 journals) Providing 24-hour high-quality service User-friendly online submission system Fair and swift peer-review system Efficient typesetting and proofreading procedure Display of the result of downloads and visits, as well as the number of cited articles Maximum dissemination of your research work

Submit your manuscript at: http://papersubmission.scirp.org/

Or contactojg@scirp.org 